\title{
New Technologies On the Street. CINEMATIC
}

\section{Lucía Amorós}

University of Murcia, Spain

doi: 10.7358/ijtl-2015-001-amor

lamoros@um.es

\section{ABSTRACT}

CINEMATC describes daily life using ICTs on the street (educational open environment) in order to promote education quality and equity through the analysis of the use and impact of ICTs. The city is seen as a classroom. CINEMATIC focuses on the creation of digital resources as learning's objects. For that reason, its aims are a) education, b) web development and c) television broadcasting. Then, as a result CINEMATIC is going to evolve as a film. The idea is to conceive and expose the process as a metaphor of Quantum Levitation. In this case, a professional relationship between mentor (superconductor) and student (magnet) is work in progress upon a holistic paradigm. Methods include collaborative work, and assessment and evaluation processes are based on the MEET model. CINEMATIC works in a flexible way. Therefore, it receives and assesses requests for support in an ongoing manner. Consequently, there is no deadline.

Keywords: assessment; cinema; educational technology; learning objects; Sciences's teaching; interpersonal communication; street education.

\section{CINEMATIC ${ }^{1}$}

- Can you give me one euro? Where has he slept? Why did not you like the meal? What are they talking about? Who sleeps in that room? Is not this a beautiful place? Could you tell me where 6A bus goes? Who smoked this? Do you know if he is coming with? Could you tell me how are you? - Asking questions on the street it can happen that it is not unusual to invert both the subject and the meaning. It is common to ask 'echo questions' to show interest or emphasis in

1 In Spanish languaje Comunicación Interpersonal En Medio Abierto con Tecnologías de la Infomación y de la Comunicación. 
a positive sentences as well. In the line of Martínez (1998), who describes interpersonal communication for business, CINEMATIC is the first interpersonal communication I have ever had on the street, in this case as a street educator.

Nowadays professional experiences move further; in my case, focusing on educational technology sculpts the way to be a street educator. In this sense, whilst in the American countries it was researching and working upon higher education, in the European countries it mades a free work as a nanny, as a lifelong learner or as a volunteer. I have specially force experienced it since 2007 becoming a user of social helps, unemployed benefits, free resources, free cultural activities even all and all a consumer of public and urban spaces.

Moreover, and for that reason, CINEMATIC is the work on the street like part of a job of educators and pedagogues. Other common terms such as educators on the street, urban pedagogy even outreach social work can be used. For further discussion about these terms see Sáez (1992), Giraldi and Boevé (2008), Iaving and Whitmore (2013).

Highlighting educational media, according with Blázquez (1984) and his classification of educational resources, CINEMATIC is working in an open environment as well as an educational resource such an open media in the line of educational technology.

In this sense as an educator, the daily life activities have taken part in different levels of split shifts, continuous days, working full-time or part-time, being dismissed, getting a new job, get to work and earning a salary.

These periods of professional growing have been offering a long experience to work on the street. In particular, in the line of new media, CINEMATIC is a crew, a script, a creation, a storyboard, learning and filming, from the street to CAMON Laboratory. In other words, people have the possibility of being part of the project (see Figure 1) according to his or her preferences, necessities and leisure time. CINEMATIC is a social intervention by social interactions on the street.

The role of street educator has been variously described. Giraldi and Boevé (2008) said that "Street educators have a general perspective, [...] what counts is how to listen to it, how one builds from it and formalizes it" (21). For that reason CINEMATIC is something which is always true or something that always happens as a result of someone else. Therefore CINEMATIC is just an idea, not a plan, and the script is neither a solid argument, nor a stable dialogue. But orality.

As McLuhan recognized (1964), the written word offers a sequence, a sort of act separated or specialized, where there is a little opportunity of participation. Nevertheless, orality means a reaction around of our situation, a reaction in tone and gesture on the act of talk. In addition, the word that we talk is a dramatic implication of all our senses. 


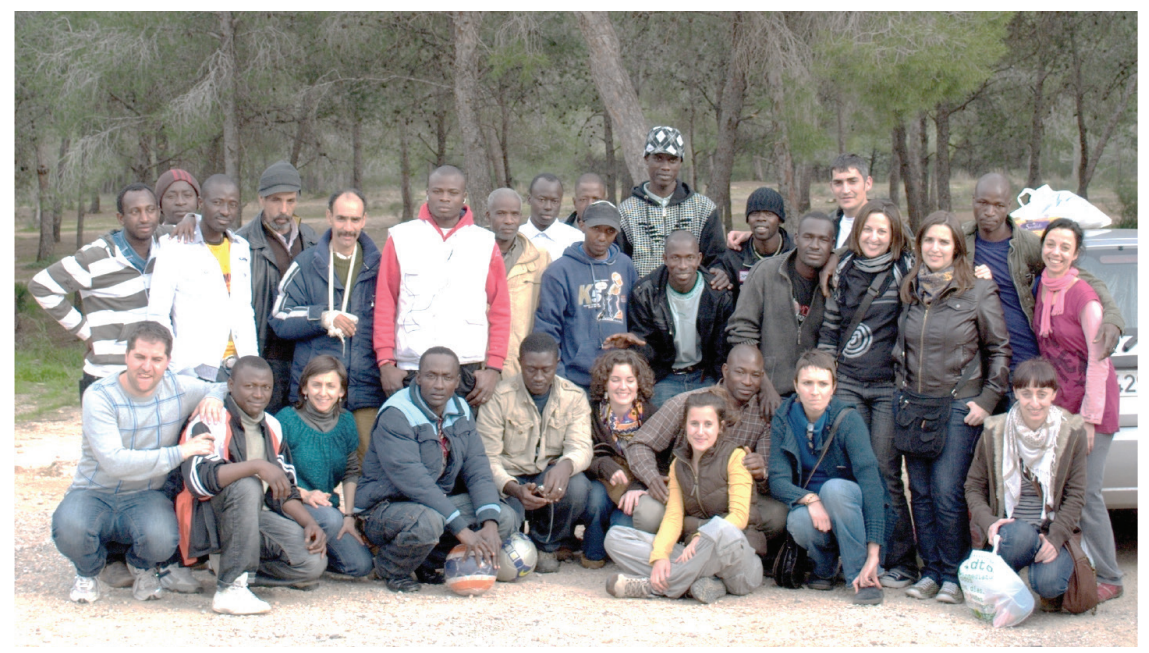

Figure 1

We were enjoying an autum Sunday in Murcia's montains. Both ONGs Imperdible and Solidarios. org de Murcia organized a Sunday-morning with games and food. We played football, we chatted with each other. After an active morning, we ate handmade paella. We learned to play step by step.

Cars and drivers could pick up all participants and they were back to the city after the activities, including the dog which does not appear on this picture. Photo courtesy of Solidarios.org - Murcia.

The creation will be part of everybody if everybody loves that creation. A Street workers workshop in Spain (Giraldi and Boevé 2008) recognize that "the individual is the true meaning of the intervention, and it is he who must decide the pace, the theme and take the steps that are necessary to change his situation. Our help is only a support for people's capacities to transform their reality and the world" (21). According to this idea, sources have to be used as tools to sustain volitive actions.

Finally, CINEMATIC is a construction of interactions for instance special answers according to specific questions. The human being, in himself or in herself is an all. An example of this idea was shown in the mid-1950s by the Midcity Project, operated in Boston (Decker et al. 2008): a project focused on community, family, and gang. The program succeeded in the line of maintain interactions. I will returned to this point later.

\subsection{Context and Backgrounds}

According to Giraldi and Boevé (2008) people for whom being on the street has become lifestyle is a global phenomenon. That reality is part of our contem- 
porary era, and it is a characteristic of Europe too. Then if we resolve the term of social exclusion, we will understand better some aspects of CINEMATIC.

As a matter of fact, social exclusion is not just an economic poverty. Nowadays, the person considered in social exclusion is generally speaking an invisible person. In other words, the social category of analysis called social exclusion peak up other elements such as cultural, environmental, educational and/or political factors. Subsequently, people socially excluded are a hidden population whose social existence is denied and away from decision makers. Commonly, the point of view of governments and institutions are reduced to an "irregular doctrine" that included "abnormal or socially deviant" with a denied recognition as individuals with legal rights. This cannot be justified on the grounds of human rights after all.

In this sense, educational models do not help so much as well as social policy and institutional models Giraldi and Boevé (2008). Furthermore, social science has kept its distance because it is still going to talk about "homeless people" or "people in need". In addiction, research articles quote one each other but they are not supporting any kind growth with new knowledge and this doesn't help to understand the complexity of the phenomenon. Therefore, the contribution with new ideas in order to understand the street phenomenon embracing a broader vision in the speech of "street populations" will give us a new dimension. These paradigms favor the creation of an innovative thought process and a new social practice.

Moreover, CINEMATIC uses information and communication technology (ICT) on the street to observe the city as a classroom and people as pupils. Important works as Pedagogy of the Oppressed by Freire (1970) have to be mentioned and cultural considerations by E.T. Hall $(1959,1977)$ have to be recognized. Simultaneously psychomotor intervention by Arnaiz (1987) and collaboration methods by Prendes $(2000,2003)$ have been used as well.

Kuskis and Logan (2012) suggest that two ways from McLuhan are considered in the field of media ecology and contemporary education. Firstly his point of view from the arrival of digital technology according to his writings from the 1950s until 1980. Secondly, his principaia related to the media ecology focused on his popular sentence 'the medium is the message'. (McLuhan 1964)

\subsection{Interpersonal Communication}

Communication between people is part of our social characteristics as human beings on the ground of orality, dialogue and social interactions driving the description of interpersonal communication. Non-oral communication, such as interpersonal zones, was studied by Hall (1959). 
Martínez (1998) offered a sum of questions, scripts, and tips to guarantee an interpersonal communication. In the field of media, Katz' research focused on the relation between mass and interpersonal communication, conversation (interpersonal networks), social psychology, sociology, and processes and effects (Birk-Urovitz and Birk-Urovitz 2012) too.

\subsection{Interactivity}

According to De Kerckhove (1997) interactivity is a relationship between people and environment. Simplifying, he talked about links in an artificial context, therefore the relationship between the person and the digital environment defined by the hardware that connects each other is the interactivity. For him interactivity is touch where networks are extensions of touch too. "Proper communications require feedback to confirm that the message has been received, even if it is just the return information on a data string - that is the truly "tactile" dimension of the relationship, and the essence of presence". (1997: XXVI prologue)

Subsequently, Palangi (2012) considered the term interactivity as a system of communication which offers answers, participation, or understanding information. This term has a link with educational technology and multimedia. Furthermore, interactivity, in human-to-human systems, involves a sense of collaboration. In other words, interlocutors will be interested in guarantee a succeful outcome to the process of communication.

\subsection{Social Intervention}

Social intervention in the field of media and communication considers social interactions. And there are recently marks on it.

De Kerckhove (1997) showed that interactions are a capacity. Therefore, the capacity that guarantees our own autonomy can be called interaction which in CINEMATIC context is being guaranteed by a movie creation, a movie that offers playing as a sort of a comedy following the own interpretation, a full engagement of a deep contact among us.

Baudrillard, the French critic of contemporary society and culture, offered reflections on media and communication and they have been salient in various academic domains. In his Postmodern Social Theory, entertainment, information and communication technologies provide intense experiences. They evolve to banal everyday lives as well as codes and models structure social interaction (Kellner 2012). The "hyperreality" of new media land with the Ecstasi of Communication. 
According to Tim Berners Lee's invention (Danesi 2012a), sites such as Facebook and You Tube reshape our human social interaction. As we could recognize, the context, that environment where people make social interactions, is both much bigger and different than years ago. But in essence, we keep a dialogue.

Danesi (2012b) recognized that Bakhtin encompasses social interaction with dialogue. It allows people to give voice to their consciousness. Then he recognizes three main forms of self-awareness and identity - 'I-for-myself' (unreliable source of identity), 'I-for-the-Other' (it developes a true sense who we are because of views of others), and 'Other-for-me' (the way in which others made their own self-identity). Therefore, identity is something that is never finished and the reason to understand people's changes. We never really fully reveal ourselves as we truly are.

\section{HOW CINEMATIC WORKS}

According to Decker et al. (2008) and suggestions from Iaving and Whitmore (2013), CINEMATIC serves two major functions. Whereas it is an essay to link at risk youth and adults to services across to prosocial activities looking for their prosocial behaviours. CINEMATIC offers activities which youth and adults are learning to play, with his or her own level of engagement. CINEMATIC tries to insure these youths and adults to gain a natural and free communication and disrupt violence behaviours, new thinking outside of drugs and/or new professional possibilities.

Subsequently, the star shows her work. She picks up any videos from You Tube for instance http://www.youtube.com/watch?v=_oijeUACFf0 where moomy gets out after her divorced (see Figure 2).

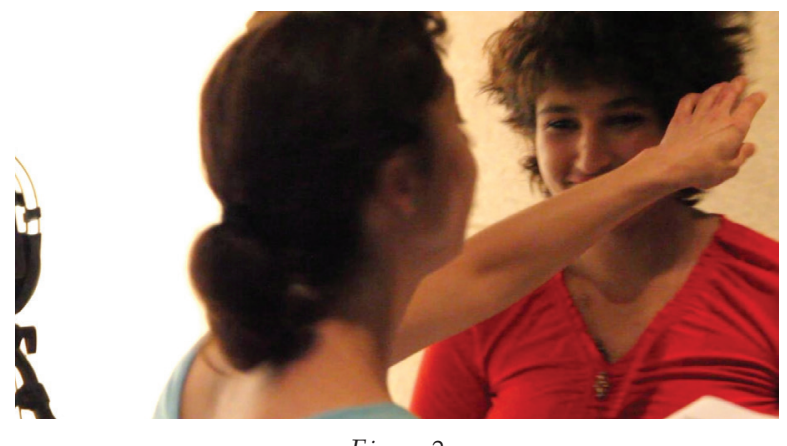

Figure 2

We were enjoying an autumn day in CAMON-Murcia's Laboratoty. Both star and filmmaker wish a modern hairstyle in the sequence 32. Therefore, it is the moment of a physical touch to guarantee trust, psychomotricity. Photo courtesy of José Antonio Quesada Sáez. 
Spontaneously, advanced technologies are part of this natural and free communication. We demand them and we delight with them, for instance, mobile phone, tablet, video camera, computer as well as free space web as CAMON (see Figure 3) or Dropbox available in https://www.dropbox.com, Vimeo even You Tube or Google anyway.

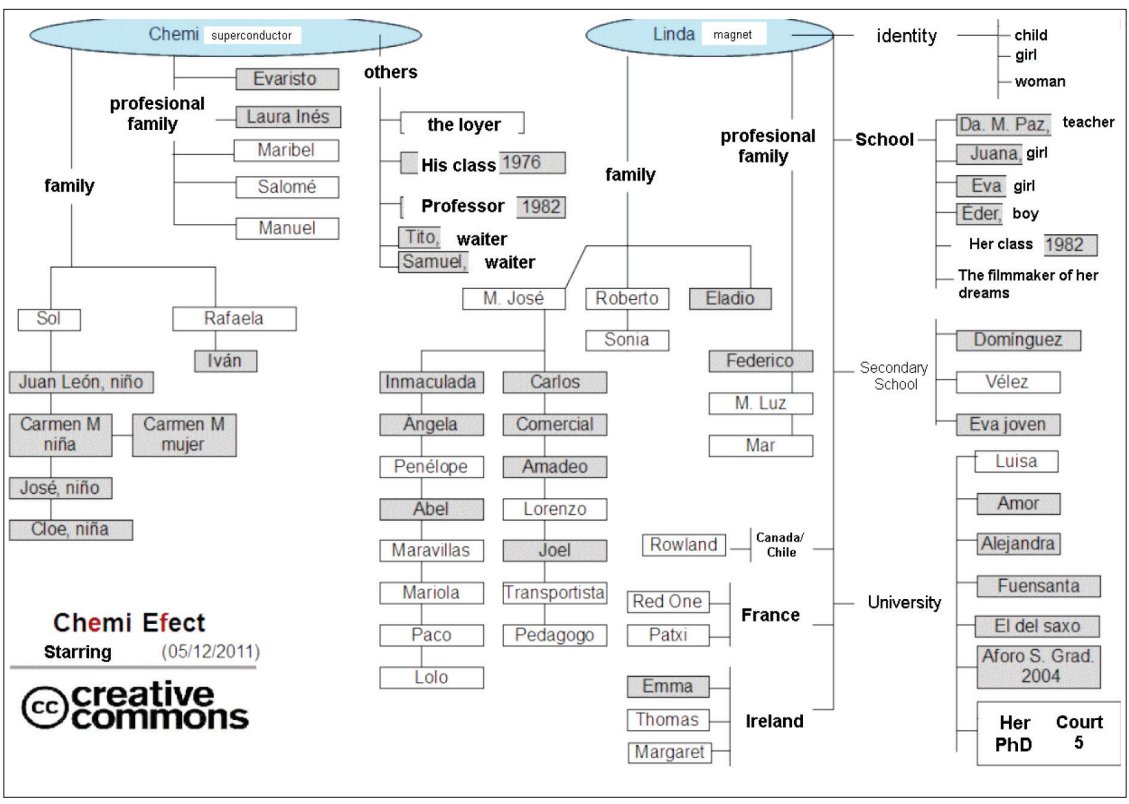

Figure 3

We were "The crew of actors must to be done before shooting". That is necessary to look for people and describe them their role. Figure hadded courtesy of CAMON-Murcia Laboratory. URL: http://www.tucamon.es/conte ntenido/actores-y-actrices.

According to sequences, the script offers schemes about the movie's rhythm (see Figure 4) and how every idea is developed (see Figure 5). Movie Montage's aim is to inform to the audience rather than to create feelings to them. In other words, montage gives knowledge to the audience.

'Storyboard 1' (see Figure 6) is not a common work in this film, neither it is Jaws (1975) by Steven Spielberg. However, storyboard draws actions, scenes, and sequences. Therefore, usually it helps to create the scenario and to visualize technical script as well. In this case, the storyboard used free software that was included in the mobile phone. CINEMATIC has 6 storyboards in magnet's part of the script and 0 storyboard in the superconductor's part of the script. 


\section{Metric a filmica}
A 46
B $\quad$\begin{tabular}{l|l|l|l|l|l|l|l|l|l|l|l|l|}
\hline 47 & 48 & 49 & 50 & 51 & 52 & 53 & 54 & 55 & 56 & 57 & 58 & 59 \\
\hline
\end{tabular}
\begin{tabular}{l|l|l|l|l|l|l|l|l|l|l|l|l|}
\hline 1 & 2 & 3 & 4 & 5 & 6 & 7 & 8 & 9 & 10 & 11 & 12 \\
\hline
\end{tabular}
\begin{tabular}{|l|l|l|l|l|l|l|l|l|l|l|l|l|l|l|l|l|l|l|l|l|}
\hline 13 & 14 & 15 & 16 & 17 & 18 & 19 & 20 & 21 & 22 & 23 & 24 & 25 & 26 & 27 & 28 & 29 & 30 & 31 & 32 \\
\hline
\end{tabular}
\begin{tabular}{ll|l|l|l|l|l|l|l|l|l|l|l|l|}
\hline & 33 & 34 & 35 & 36 & 37 & 38 & 39 & 40 & 41 & 42 & 43 & 44 & 45 \\
\hline
\end{tabular}
\begin{tabular}{ll|l|l|l|l|l|l|}
\hline$\quad 60$ & 61 & 62 & 63 & 64 & 65 & 66 \\
\hline
\end{tabular}

\section{Figure 4}

'Métrica filmica' shows the rhythm of the movie. It is just a shy representation by sequences that offers a quickly view. Chemi Effect has 66 sequences.

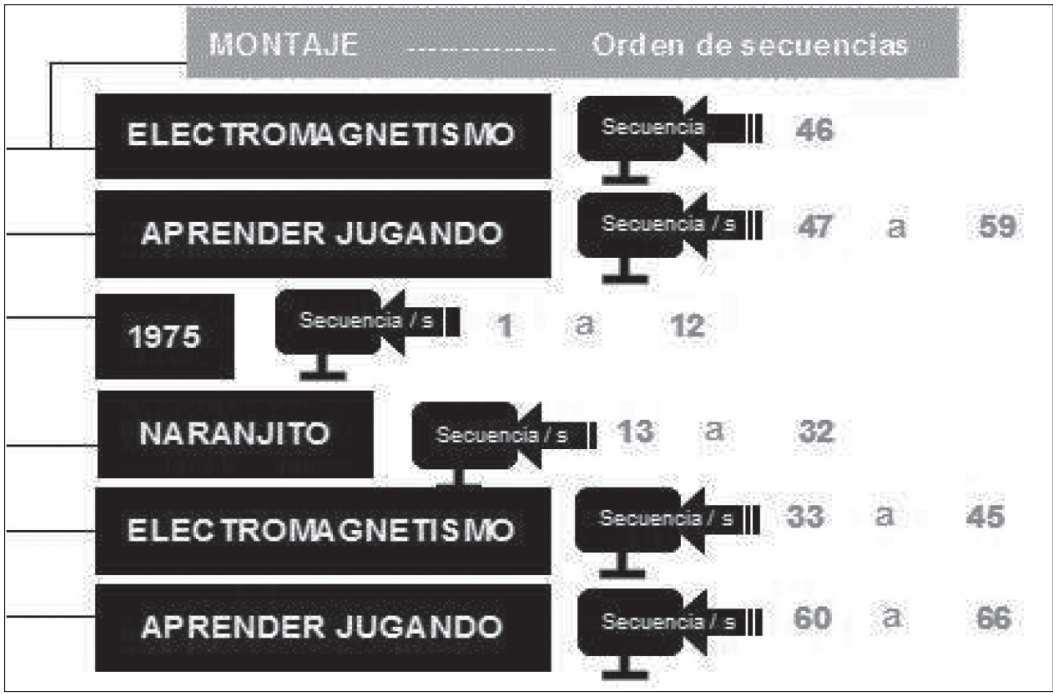

Figure 5

'MONTAJE. Orden de secuencias' as Movie Montage focuses on the film as a container. However, it keeps content in the line of the concept of Quantum levitation such as 'Electromagnetism' with 7 sequences, 'Learning teaching' with 26 sequences, '1975' as the background with 12 sequences and 'Little orange' called Naranjito with 20 sequences. 


\section{el efecto chemi | storyboard 1}

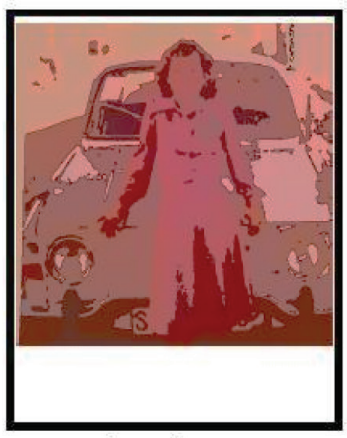

Escena: 1 Plano:

Sonido:

Descripción:

Categoría: 1975 narra

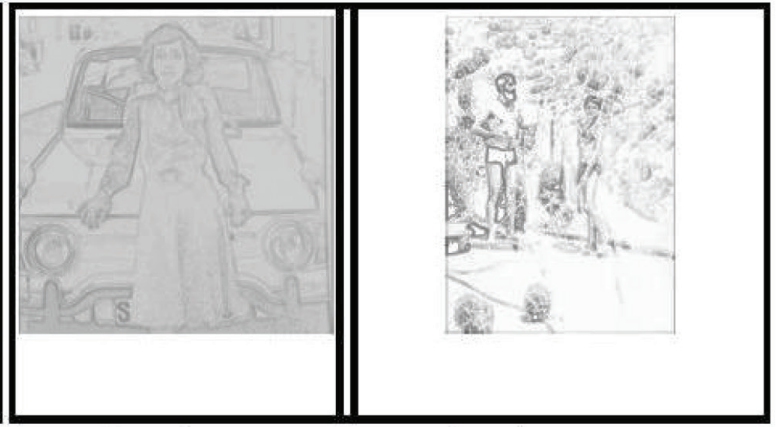

Escena: 1 Plano:

Sonido:

Descripción:

Categoría: 1975 narra
Escena: 1 Plano:

Sonido:

Descripción:

Categoría: 1975 narra

Figure 6- 'Storyboard 1' from sequence 1.

\section{Aims, Methods AND Assessment}

CINEMATC describes daily life using ICTs on the street. ICTs will be analyzed as a socially accepted element upon the point of view of social interactions in order to promote quality education and equity through the analysis of the use and impact of ICTs on the street (educational open environment). The city is seen as a class.

CINEMATIC focuses on the creation of digital resources as learning's objects. For that reason, we are talking about a) education, b) web development and c) television broadcasting.

CINEMATIC counts on support from social services, businesses, and citizens (crowdfunding) from which we use participant observation as an action research methodology in the line of cultural studies. For instance, active methods of teaching are necessary here, as Engstrøm et al (2007) described years ago. In this case CINEMATIC uses non-formal interviews, accompaniment, research diary, photography, and video as well. Giraldi and Boevé noted "there is no universal theoretical framework on the methodology of street work" $(2008,10)$.

The work process involves the design, development, and evaluation of educational digital content as I said before. Then, as a result CINEMATIC 
will evolve as a film. It is shooted in studio. The idea is to conceive this process according to the concept of Quantum Levitation as a metaphor. In this case, a professional relationship between mentor (superconductor) and student (magnet) is a work in progress upon an holistic paradigm.

Parallely, assessment and evaluation process apply the MEET model: a mixed method helpful for a traditional teaching-learning context. Concerning this method, the MEET model has already assessed and evaluated the activities of teaching Science in the context of Secondary School (Zamarro and Amorós 2011), in University (Amorós 2013) and in entertainment (Amorós and Díaz 2011).

CINEMATIC works in a flexible way. Therefore, it receives and assesses requests for support in an ongoing manner. Consequently, there is no deadline.

\section{AKNOWLEDGES}

City of Murcia, City of Barcelona, Local Police Forces of the Region of Murcia, Jesus Abandonado Fundation of Murcia, Neri Association, La Mejillonera Bar, Emergency Night Shelter's Center of the City of Barcelona, INCORPORA Program of La Caixa, Local Service of Red Cross, Employment Services and Training (SEF-SEPE), PERSON from Regional Confederation of Business Organizations of Murcia (CROEM), McLuhan Program in Culture and Technology, CAMON MURCIA's Laboratory and National Police Corps of Spain, with special aknowledge to Paqui and the Inspector Juan Iglesias Maldonado.

Moreover to Valentín Sánchez Montiel, Juan José Pavo Martínez, José Ángel Puche Simarro, Oistric Gheorghe Leontin, Josefa Pérez Giménez, Laura González Martínez, Paco Parra Gallego, Jesús Fernández Torres, Paulo Jorge Guerra du Amaral e Abrey, Joaquín Tortillol Molina, Cristian, Víctor Izquierdo Baeza, José Antonio Quesada Sáez and Ramona Rey.

\section{REFERENCES}

Amorós, Lucía, eds. 2013. Nuevas tecnologías para la calidad y la equidad de la educación. Saarbrücken (Germany): EAE.

Amorós, Lucía, and M Dolores Díaz. 2011. Del Bingo al Facebook y tiro porque me toca. Madrid: Dykinson [e-book].

Arnaiz, Pilar. 1987. Fundamentación de la práctica psicomotriz. En B. Aucouturier. Murcia: Instituto de Ciencias de la Educación, Universidad de Murcia, 2. 
Birk-Urovitz, Alexandra and Elizabeth Birk-Urovitz. 2012. "Katz, Elihu.” In Encyclophedia of Media and Communication, edited by Marcel Danesi, 382-383. Toronto: Toronto University Press.

Blázquez, Florentino. 1984. "Medios didácticos. El medio ambiente y otros recursos para la enseñanza”. In Didáctica General, directed by Oscar Sáenz, 69-91. Madrid: Anaya.

Danesi, Marcel. 2012a. "Berners-Lee, Tim." In Encyclophedia of Media and Communication, edited by Marcel Danesi, 59-60. Toronto: Toronto University Press.

Danesi, Marcel. 2012b. "Dialogue." In Encyclopbedia of Media and Communication, edited by Marcel Danesi, 236-237. Toronto: Toronto University Press.

Decker, Scott H., Tim S. Bynum, Jack McDevitt, Amy Farrell and Sean Varano. 2008. Street Outreach Workers: Best Practices and Lessons Learned. Last access February 8, 2014. URL: http://www.mass.gov/eopss/funding-and-training/justiceand-prev/grants/shannon-csi/shannon-pub-4.pdf.

Engstrøm, Vegard, Heimo Latal, Leopold Mathelitsch, and Gerhard Rath, eds. 2007. SUPERCOMET. Superconductivity Multimedia Educational Tool, phase 2.Teacher Guide. Last access February 28, 2014. URL: http://www.fisica. uniud.it/mosem/PDF/SC2_teacher_guide_20071105_GR.pdf.

Freire, Paolo (2000) [1970]. Pedagogy of the Oppressed. NY: Continuum. Last access February 4, 2014.URL: http://www.users.humboldt.edu/jwpowell/edreformFriere_pedagogy.pdf.

Giraldi, Maïta, and Edwin de Boevé, eds. 2008. International Guide on the Methodology of Street Work througthout the World. Last access February 9, 2014. URL: http:// www.travailderue.org/wp-content/uploads/2012/08/international_guide.pdf.

Hall, Edward T. [1959] 1996. The silent languaje. New York: Fawcett World Library.

Hall, Edward T. [1977] 1990. Beyong culture. New York: Anchor Books.

Iaving, Don, and Simon Whitmore. 2013. On The Street. A Practical guide for New Social Street Workers. Last access February 8, 2014. URL: http://www.travailderue.org/wp-content/uploads/2014/01/Toolkit-New-street-workers.pdf.

Kellner, Douglas. 2012. Ibaudrillard, Jean. In Encyclophedia of Media and Communication, edited by Marcel Danesi, 46-52. Toronto: Toronto University Press.

Kerkhove, Derrick de. 1997. Connected intelligence. The arrival of the web society. Toronto: Somerville house publishing.

Kuskis, Alexander and Logan, Robert. 2012. "A Historiacl View of Education from the Perspective of Marshall McLuhan and Media Ecology." International Journal of McLuban Studies 2: 27-40. Barcelona: UOC Press.

Martínez, Francisco. 1998. La comunicación interpersonal. Madrid: ERITEL. Inedit.

McLuhan, Marshall. 1996 [1964]. Comprender los medios de comunicación. Las extensions del ser bumano. Barcelona: Paidós. Understanding Media. The Extensions of Man. Cambridge (Massachusetts): The MIT Press. 
Palangi, Angela. 2012. "Interactivity." In Encyclophedia of Media and Communication, edited by Marcel Danesi, 363-634. Toronto: Toronto University Press.

Prendes, Maria Paz. 2000. "Trabajo colaborativo en espacios virtuales". In J. Cabero, F. Martínez \&. J. Salinas, eds. Medios Audiovisuales y Nuevas Tecnologías para la formación en el S. XXI. (2 ${ }^{\text {nd }}$ ed.), 223-245. Murcia: DM.

Prendes, Maria Paz. 2003. "Aprendemos... ¿cooperando o colaborando? Las claves del método.” In F. Martínez, eds. Redes de comunicación en la enseñanza. Las nuevas perspectivas del trabajo corporativo, 93-128. Barcelona: Paidós:.

Sáez, Juan. 1992. "Los educadores sociales y ¿tecnólogos o intelectuales?”. Pedagogía social 7: 179-189. http://dialnet.unirioja.es/servlet/articulo? codigo=2541892.

Zamarro, José Miguel and Lucía Amorós, eds. 2011. Nuevas tecnologías aplicadas a la enseñanza de las ciencias. Alcalá de Guadaíra (Sevilla): MAD - Eduforma. 